\title{
K-CASEIN GENE POLYMORPHISMS IN RIVERINE AND SWAMP BUFFALO IN INDONESIA
}

\author{
A.O. Rini ${ }^{1}$, C. Sumantri ${ }^{1}$ and E. Damayanthi ${ }^{2}$ \\ ${ }^{1}$ Faculty of Animal Science, Bogor Agricultural University, \\ Jl. Agatis, Bogor 16680 - Indonesia \\ ${ }^{2}$ Faculty of Human Ecology, Bogor Agricultural University, \\ Jl. Meranti, Bogor 16680 - Indonesia \\ Corresponding E-mail: annisa.oktavia@gmail.com
}

Received November 23, 2013; Accepted January, 30, 2014

\begin{abstract}
ABSTRAK
א-kasein dikenal sebagai gen yang berperan mengontrol protein susu, memiliki peran penting dalam koagulasi dan curdling susu, terutama dalam proses pembuatan keju. Penelitian ini bertujuan untuk mengidentifikasi keragaman gen $\kappa$-kasein kerbau lokal di Indonesia. Sampel yang digunakan adalah 40 ekor kerbau sungai dan 250 ekor kerbau rawa. Penelitian ini menggunakan metode PCRRFLP, gen $\kappa$-kasein diamplifikasi menghasilkan fragmen sepanjang $157 \mathrm{pb}$ di exon 4. Produk amplifikasi dipotong dengan enzim restriksi EcoRV yang mengenal situs potong gen $\kappa$-kasein pada ekson 4 di nukleotida GAT|ATC, menghasilkan keragaman pada posisi basa ke- 23 pb akibat perubahan basa Ile (ATC) pada alel T menjadi Thr (ACC) pada alel C. Genotiping gen $\kappa$-kasein pada kerbau sungai menghasilkan dua tipe alel, yaitu alel $\mathrm{C}(157 \mathrm{pb})$ dan $\mathrm{T}(136$ dan $21 \mathrm{pb})$. Kedua alel tersebut menghasilkan tiga genotipe, yaitu CC, TT, dan CT. Frekuensi alel C ditemukan lebih tinggi dibandingkan alel T. Gen $\kappa$-kasein pada kerbau rawa ditemukan monomorfik karena tidak adanya variasi alel (alel C). Nilai heterozigositas kerbau sungai dan rawa ditemukan rendah. Nilai PIC kerbau sungai dan kerbau rawa berkisar pada 0.000-0.288. Nilai indeks fiksasi gen $\kappa$-kasein pada kerbau sungai rendah (Siborong-borong SBBC = -0,0036; Deli Serdang = -0.025), namun pada kerbau rawa terjadi fiksasi. Penelitian ini menunjukkan bahwa terdapat keragaman gen $\kappa$-kasein pada kerbau sungai namun pada kerbau rawa ditemukan monomorfik.
\end{abstract}

Kata kunci: Kerbau sungai, kerbau rawa, gen $\kappa$-kasein|EcoRV, PCR-RFLP, keragaman genetik

\section{ABSTRACT}

Kappa-casein ( $\kappa$-casein) gene is known as a gene that plays a role in controlling milk protein and also play a crucial role in the coagulation and curdling of milk. This study was aimed to identify polymorphisms of the $\kappa$-Casein gene of local buffaloes in Indonesia. A total number of 40 heads of riverine buffalo and 250 heads of swamp buffalo. This study used PCR-RFLP method, which amplification of the $\kappa$-Casein gene resulted an amplicon with length of $157 \mathrm{bp}$, located in exon 4 . The amplified fragment were digested with EcoRV restriction enzyme, which cut the $\kappa$-Casein gene in exon 4 at nucleotides of GAT|ATC, revealed the presence of one polymorphism at the base position of $23 \mathrm{bp}$ that occurs with a substitution of Ile (ATC) of the T genetic variant into $\mathrm{Thr}$ (ACC) of the $\mathrm{C}$ genetic variant. Genotyping $\kappa$-Casein gene in riverine buffalo produced two types of allele, namely $\mathrm{C}$ allele (157 $\mathrm{bp}$ ) and T allele (136 and $21 \mathrm{bp}$ ). These two alleles resulted in three types of genotypes, namely CC, CT, and TT. Frequency of the $\mathrm{C}$ allele was dominant to $\mathrm{T}$ allele. $\kappa$-Casein gene in swamp buffalo was monomorphic with one allele, namely $\mathrm{C}$ allele. Heterozygosity value of riverine and swamp buffaloes were low. PIC value in riverine and swamp buffalo ranged 0.000-0.288. Fixation index of $\kappa$-Casein gene in riverine buffalo was low (Siborong-borong SBBC $=-0,0036$; Deli Serdang $=-0.025$ ), but in swamp buffalo was in fixation. This study showed that $\kappa$-Casein|EcoRV were polymorphic in riverine buffalo and monomorphic in swamp buffalo.

Keywords: Riverine buffalo, swamp buffalo, $\kappa$-Casein|EcoRV, PCR-RFLP, polymorphisms 


\section{INTRODUCTION}

Beside as a meat producer and worker, buffalo also a producer of milk. In Indonesia, the production of buffalo milk is very slight. Contrast, in India buffalo is an important milch animal as more than $60 \%$ of the total milk produced is buffalo milk (Patel et al., 2007). Buffalo is considered to be a better converter of fibrous feeds into milk, and to be more resistant to disease and local climatic condition. In Indonesia, there were very little work has been carried out on buffalo genetics that could give an effective implementation on breeding program. Nowadays selection program has come to molecular approach that can give fast and efficient result. Selection on molecular markers is more reliable than other methods (Othman, 2005). Progress in molecular technology allows selection to be done at molecular level and have already uncovered a large number of genetic polymorphisms at the DNA level which are being used as genetic markers.

Milk and milk products is important for feeding because supply nutrients, energy, high quality protein, vitamins and mineral requirements. The composition of the milk of different species varies in the percentages of these constituents. All milks contain the same constituents, but in varying amounts (Otaviano et al., 2005). Milk proteins are usually divided into two fractions. The first fraction is soluble fraction, named whey protein, constitutes the $\alpha$ lactoalbumen and $\beta$-lactoglobulin. The second fraction is insoluble fraction, named whole casein, constitutes 4 different casein (alpha S1, alpha S2, Beta and kappa-caseins) (El-Rafey and Darwish, 2007; Rachagani and Gupta, 2008; Unsal et al., 2008). The casein fraction of milk proteins significantly influences the composition and physic chemical properties of the milk (Grosclaude, 1988).

$\kappa$-Casein is one of the most important milk proteins with 19,800 dalton molecular weight and 169 amino acids. The $\kappa$-Casein gene in buffalo is divided into 5 exon and 4 intron. In water buffalo the $\kappa$-Casein gene was mapped on chromosome 7 (Iannuzzi et al., 1998). Variant B of $\kappa$-Casein gene result by means of point mutation (T/C) at position exon 4, due to increasing efficiency production cheese of milk (Henderson, 1971; Medrano and Aguilar, 1990). Mutations in this exon are responsible for quali-quantitative differences of gene expression in cattle and goat
(Di Stasio et al., 2000; Chiatti et al., 2005). Four single nucleotide polymorphisms are reported in literature: two at the exon 2: $\mathrm{G}$ versus $\mathrm{T}$ at codon 4 (ArgAGG versus SerAGT) and T versus G at codon 8 (ValGTT versus GlyGGT) both in the signal peptide (EMBL a.n. DQ191173 and DQ191174); and two at the exon 4: T versus $C$ at codon 135 (IleATC versus ThrACC) and the silent mutation $\mathrm{T}$ versus $\mathrm{C}$ at codon 136 in Murrah Buffaloes (Mitra et al., 1998).

In sperm catalogs, $\mathrm{BB}$ or $\mathrm{AB}$ genotypes indicator ideal genotypes of milk production for use in cheese making (yielding) factories that due to decreasing coagulation time and increasing curdling stability of milk. In this reason, domesticator that their herd's milk are used for cheese making, use sperms with $\mathrm{AA}$ or $\mathrm{BB}$ genotypes until increase $B$ allele frequency in herd and gradually increase ideal genotype of this gene in their domestics (Alipanah et al., 2008; Dayem et al., 2008).

Information on polymorphisms of $\kappa$-Casein gene in buffalo in Indonesia is very limited. This study was aimed to identify the polymorphism of $\kappa$-Casein gene by using PCR-RFLP technique as a fast efficient and low cost method in Indonesia local buffaloes.

\section{MATERIALS AND METHODS}

\section{Sources of Sample}

Blood samples used totally were 290 buffaloes, that were collected from 40 riverine buffaloes from Siborong-borong SBBC (20 heads) and Deli Serdang (20 heads); as well as a number of 250 swamp buffaloes from Banten (30 heads), Semarang (30 heads), Mataram (30 heads), South Sulawesi (30 heads), Aceh (67 heads), Riau (25 heads), North Sumatera (24 heads), dan West Sumatera (14 heads). Blood samples were collected from the jugular vein using vacuum tubes containing with heparin. Blood samples were stored in absolute alcohol.

\section{DNA extraction}

Blood samples were collected from each buffalo in $10 \mathrm{~mL}$ non anticoagulan polypropylene tubes. Blood samples then were mixed with $96 \%$ ethanol. The process of DNA isolation used phenol-chloroform method (Sambrook et al., 1989) modified by Andreas et al., (2010) then were dissolved in TE buffer. Genomic DNA was stores at $-20^{\circ} \mathrm{C}$ until amplification with polymerase chain reaction (PCR). 


\section{Polymerase Chain Reaction (PCR)}

Amplification of Polymerase Chain Reaction (PCR) was carried out using specific primer by following from relevant references (Masina et al., 2007) GenBank Acc No. AM900443 which previously being modified for parts of exon 4 . The primer design using PIRA technique which replace (cc) base become (ga) base in forward primer (Table 1). The PCR was performed in a final volume of $15 \mu \mathrm{L}$ for each reaction containing $0.5 \mu \mathrm{L}$ of genomic DNA, $5.85 \mu \mathrm{L}$ destilated water, $0.3 \mu \mathrm{L}$ of each primer, $0.05 \mu \mathrm{L}$ taq phire, and $7.5 \mu \mathrm{L} 2 \mathrm{x}$ PCR buffer. The reaction mixture was subjected to an initial $5 \mathrm{~min}$ of denaturation $95^{\circ} \mathrm{C}$, followed by 35 cycles of denaturation $95^{\circ} \mathrm{C}$ for $20 \mathrm{sec}$, annealing $60^{\circ} \mathrm{C}$ for $30 \mathrm{sec}$, extention $72^{\circ} \mathrm{C}$ for $40 \mathrm{sec}$, and a final extension $5 \mathrm{~min}$ at $72^{\circ} \mathrm{C}$. Electrophoresis used to check the PCR product.

\section{Genotyping by PCR - RFLP}

Visualization of amplification was analyzed on agarose gel $1.5 \%$ containing $2.5 \mu \mathrm{L} \mathrm{EtBr}$ (ethidium bromide), $0.5 \mathrm{X}$ TBE buffer (1 M Tris, 0.9 M Boric acid, 0.01 M EDTA PH 8.0) with a $100 \mathrm{bp}$ ladder as a molecular weight marker for confirmation of the length of PCR product. For digestion by using enzyme and determination of RFLP, $5 \mu \mathrm{L}$ of PCR products was added to $0.4 \mu \mathrm{L}$ EcoRV enzyme, $1 \mu \mathrm{L}$ distilated water, and $0.6 \mu \mathrm{L}$ $\mathrm{R}$ buffer. The mixture was then incubated at $37^{\circ} \mathrm{C}$ for 16 hour. The digestion products were separated by horizontal electrophoresis (100 volts, $40 \mathrm{~min}$ ) in $2 \%$ agarose gel in $0.5 \mathrm{X} \mathrm{TBE}, 2.5 \mu \mathrm{L}$ $\mathrm{EtBr}$ and $20 \mathrm{bp}$ ladder as a molecular weight marker for confirmation of the length of PCRRFLP product visualized on UV transiluminator.

\section{Data Analysis}

\section{Genotype and Allele Frequencies}

PCR-RFLP data were analyzed by calculating the frequencies of allele and genotype (Nei and Kumar, 2000). The genotype frequencies can be determined by calculating the ratio of specific genotypes in each population, were calculated by the following formula

$$
x_{i i}=\frac{n_{i i}}{N}
$$

Allele frequency of an allele is the ratio of the overall alleles at a locus in a population. Allele frequency of $\kappa$-Casein $\mid E c o R V$ were calculated by the following formula

$x_{i}=\frac{2 n_{i i}+\sum n_{i j}}{2 N}$

Description:

$x_{i i} \quad=$ Frequency of genotypes AiAi

$x_{i} \quad=$ Frequency of allele $\mathrm{Ai}$

$n_{i i}=$ Number of genotype AiAi

$n_{i j} \quad=$ Number of genotype AiAj

$N=$ Total sample

\section{Heterozygosity}

Heterozygosity was tested (Weir, 1996) by the following formulas

$$
\text { Ho }=\sum_{i \neq j} \frac{n_{i j}}{N}
$$

Ho $=$ Heterozygosity observation

nij $=$ Number of heterozygous animal

$\mathrm{N}=$ Number of observed animal

Heterozygosity expectations ( $\mathrm{He}$ ) based on allele frequencies (Nei and Kumar 2000) were calculated by the following formulas

$\mathrm{He}=1-\sum_{i=1}^{q} x_{i}^{2}$

Description :

$\mathrm{He}=$ Heterozygosity expectation

$x i=$ Frequency of allele

$q \quad=$ Total allele

\section{Polymorphic Informative Content (PIC)}

The level of informative alleles were calculated using PIC value (Bostein et al., 1980)

Table 1. Forward and Reverse Primers for the Amplification of the $\kappa$-Casein Gene

\begin{tabular}{cc}
\hline Primer Pair Name & Primer Sequence \\
\hline$\kappa$-Casein F & 5'-GTTGAGCCTACAAGTACAgaTA-3' \\
$\kappa$-Casein R & 5'-TGTCTTCTTTGATGTCTCCTTAGAG-3' \\
\hline
\end{tabular}


by the following formula

$$
\mathrm{PIC}=1-\sum_{i=1}^{n} p i^{2}-\sum_{i=1}^{n-1} \sum_{j=i+1}^{n} 2 p i^{2} p j^{2}
$$

Description :

$p_{i} \quad=$ Frequency of allele- $\mathrm{i}$

$n \quad=$ Total allele

\section{Fixation Index}

Fixation index (Nei, 1987) in each source was obtained from equation

$$
F_{\text {ISki }}=\frac{X_{k i i}-X_{k i}^{2}}{X_{k i}\left(1-X_{k i}\right)}
$$

Description:

$\mathrm{F}_{\text {ISki }}=$ Fixation Index

Xkii $=$ Frequency of homozygot genotype $i$ in $k$ population

Xki $=$ Frequency of allele $i$

\section{RESULTS AND DISCUSSION}

\section{к-Casein Gene Amplification}

Amplification of the $\kappa$-Casein gene resulted an amplicon with the length of $157 \mathrm{bp}$, which is located in partial exon 4. The amplification fragment of the $\kappa$-Casein gene was performed in the thermocycler machine with an annealing temperature of $60{ }^{\circ} \mathrm{C}$. The amplification of $\mathrm{K}$ Casein gene fragment was carried on GeneAmp ${ }^{\circledR}$ PCR System 9700 (Applied Biosystem). Gene segment amplification products were visualized on $1.5 \%$ agarose gel as shown in Figure 1. Position of primers annealing on $\kappa$-Casein gene sequences shown in Figure 2.

\section{к-Casein|EcoRV Gene Polymorphisms}

PCR-RFLP (restriction fragment length polymorphism) using EcoRV enzyme was used to genotype the Indonesian buffaloes. This enzyme recognized and cut at nucleotides of GAT|ATC sites. Forward primer that used in this research

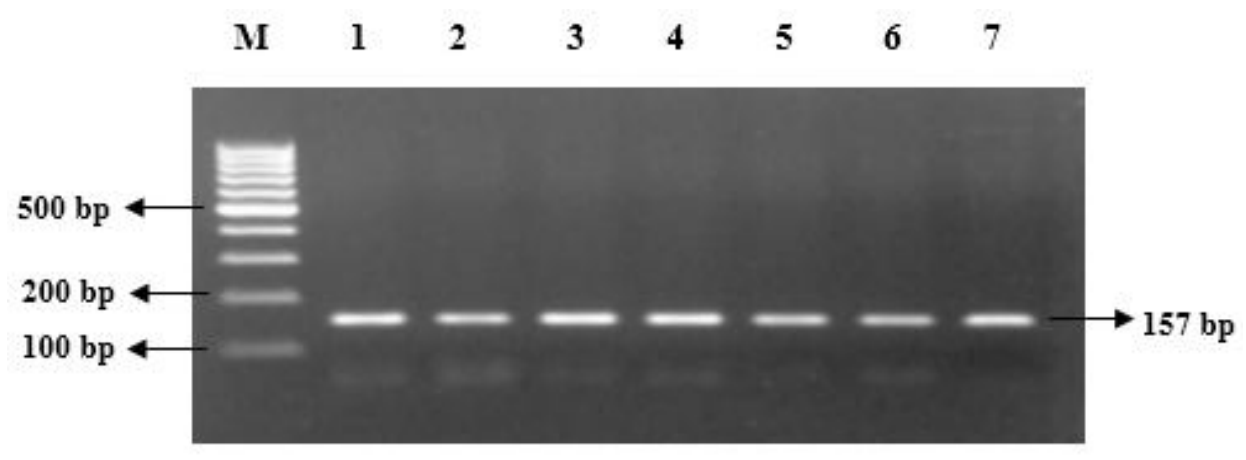

Figure 1. Visualization of $\kappa$-Casein Gene Amplification Results in 1.5\% of Agarose Gel. $\mathrm{M}=$ Marker of 100 bp; No. 1-7 = Number of sample

\section{Primer Forward}

12001 taccatcaat accattgtta gtgttgagcc tacaagtaca gatatcactg aagcaataga
12061 gaacactgta gctactctag aggcttcctc agaagttatt gagagtgtac ctgagaccaa
12121 cacagcccaa gttacttcaa ccgtcgtcta aaadctctaa ggagacatca aagaagacaa

Primer Reverse

Figure 2. The Pattern Corresponding to the Sequence k-Casein Gene in Buffalo (GeneBank Accession AM900443). Restriction Site at Position 12043 
was modified in order to get a restriction site by EcoRV enzyme. That technique known as PIRA (Primer Introduced Restriction Analysis), is widely used techniques in SNP detection. The method introduces an artificial restriction site into a PCR product by the use of a primer with a single-base mismatch close to its 3'end (Ke et al., 2001). Based on amplification results of the $\kappa$ Casein gene sequences, it was found one point of EcoRV restriction enzyme, it was in 12043 or on base position $21 \mathrm{bp}$ of the PCR products. RFLP resulted in two fragments with the base length of 21 and $136 \mathrm{bp}$, it showed $\mathrm{C}$ allele. If there was a base change at position 12045 , from the base $\mathrm{T}$ (Thimin) changing to $\mathrm{C}$ (Citosin), it caused EcoRV did not recognized and cut the fragment (bands) resulting $\mathrm{T}$ allele (Figure 3 ). Patel et al. (2007) reported his study in riverine buffalo that the restriction enzyme digestion analysis of $\kappa$ Casein indicates the presence of the two types of restriction pattern, two fragments of 266 and 84 bp for BB-genotype were observed while in the second pattern three fragments $266,134 / 132$, and 84 bp for AB-genotype were observed, but none of buffaloes indicated AA-genotype.

The diversity of $\kappa$-Casein in this study was founded in exon 4 region. Masina et al. (2007) reported in their research in water buffalo that the comparison of the sequences obtained from exons 1,2,3 and 5 did not reveal any polymorphism. As for the exon 4 , the comparison of the obtained sequences confirmed the two single nucleotide polymorphisms already reported in literature at the fourth exon ( $\mathrm{T}$ versus $\mathrm{C}$ responsible for amino acid substitution at position 135 and the silent mutation $\mathrm{T}$ versus $\mathrm{C}$ at codon 136).

Results from the PCR-RFLP of the $\kappa$-Casein|
EcoRV gene in riverine buffalo segments were polymorphic. There were three genotypes, namely genotypes CC, CT, and TT derived from two alleles, namely $\mathrm{C}$ and $\mathrm{T}$ allele. Contrast, the $\kappa$ Casein|EcoRV gene in swamp buffalo was monomorphic because it just showed one allele (T) and all of the genotypes is CC. Nei and Kumar (2000) stated that an allele was polymorphic if the frequency of allele was equal or less than 0.99 .

Three variant genotypes found in riverine buffalo of this study were CC, CT, and TT (Figure $3)$. Genotyping the $\kappa$-Casein gene, showed for the resulted $157 \mathrm{bp}$, identified for CC genotype; 136 and $21 \mathrm{bp}$ for TT genotype; and 157, 136, and 21 bp for CT genotype. The observation for $\kappa$-Casein gene polymorphisms in exon 4 are similar to the findings of Riaz et al. (2008) who noted one allele B in Nili-Ravi breed of Pakistan. Raj et al. (2008), El-Rafey and Darwish (2007) and Otaviano et al., (2005) also found monomorphism (BB) for this gene in buffaloes. However, Patel et al. (2007) found two alleles $\mathrm{A}$ and $\mathrm{B}$ for $\kappa$-Casein locus in riverine buffalo, such as in Murrah, Surti, and Pandharpuri breeds of buffalo. The diversity of $\kappa-$ Casein|EcoRV gene in buffalo (riverine buffalo and swamp buffalo) were indicated by the number of genotypes that appeared from each breeds.

\section{Genotype and Allele Frequency of the $\kappa-$ Casein|EcoRV Gene}

Results of the $\kappa$-Casein $\mid E c o$ RV gene analysis showed that the frequency of the CC genotype in all population of riverine and swamp buffaloes was higher than TT and CT genotype (Table 2). Frequency of $\mathrm{CC}$ genotype on riverine buffalo ranged $0.600-0.950$. The highest frequency of

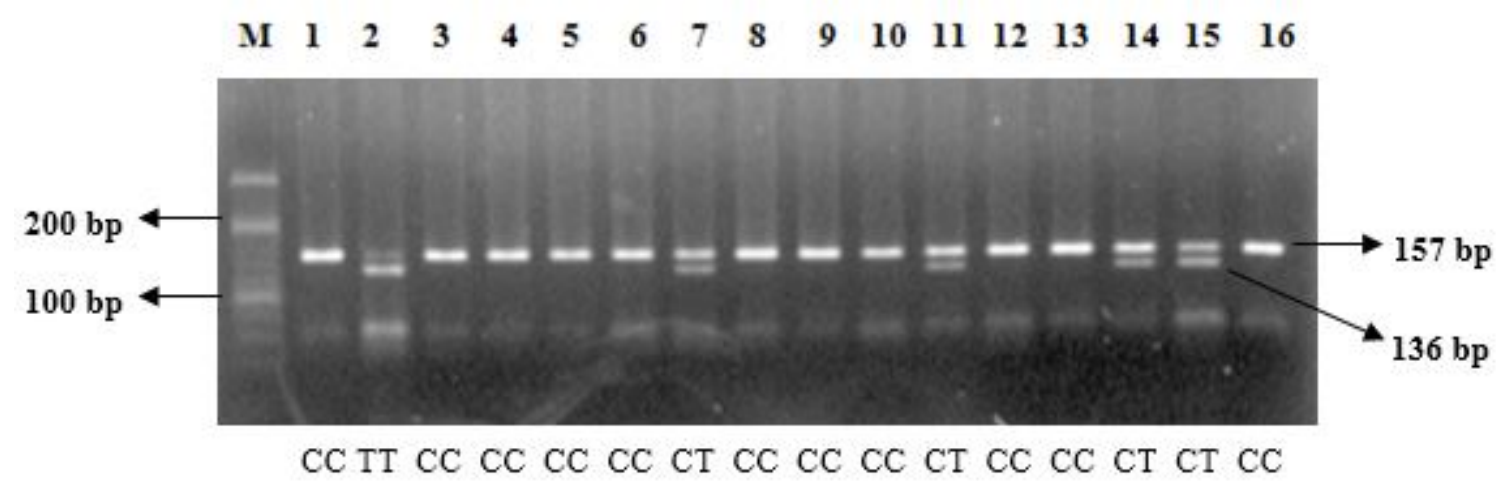

Figure 3. Result of $\kappa$-Casein Gene Fragment Using PCR-RFLP Method with EcoRV Restriction Enzyme on $2 \%$ of Agarose Gel. $\mathrm{M}=$ Marker $20 \mathrm{bp} ; 1-16=$ Number of samples; CC, CT, TT = Genotype 
Table 2. Genotype and Allele Frequencies of the $\kappa$-Casein Gene

\begin{tabular}{|c|c|c|c|c|c|c|}
\hline \multirow{2}{*}{ Buffalo Breed } & \multirow{2}{*}{ Population } & \multicolumn{3}{|c|}{ Genotype } & \multicolumn{2}{|c|}{ Alelle } \\
\hline & & $\mathrm{CC}$ & $\mathrm{CT}$ & $\mathrm{TT}$ & $\mathrm{C}$ & $\mathrm{T}$ \\
\hline \multirow[t]{3}{*}{ Riverine Buffalo } & SBBC & $0.600 \quad(12)$ & 0.350 & 0.050 & 0.775 & 0.225 \\
\hline & Deli Serdang & $0.950 \quad(19)$ & 0.050 & $0.000(0)$ & 0.975 & 0.025 \\
\hline & Sub Total & $0.775 \quad(31)$ & 0.200 & 0.025 & 0.875 & 0.125 \\
\hline \multirow[t]{9}{*}{ Swamp Buffalo } & Banten & $1.000 \quad(30)$ & $0.000(0)$ & $0.000(0)$ & 1.000 & 0.000 \\
\hline & North Sumatera & $1.000 \quad(24)$ & $0.000(0)$ & $0.000(0)$ & 1.000 & 0.000 \\
\hline & Semarang & $1.000 \quad(30)$ & $0.000(0)$ & $0.000(0)$ & 1.000 & 0.000 \\
\hline & Mataram & $1.000 \quad(30)$ & $0.000(0)$ & $0.000(0)$ & 1.000 & 0.000 \\
\hline & Aceh & $1.000 \quad(67)$ & $0.000(0)$ & $0.000(0)$ & 1.000 & 0.000 \\
\hline & South Sulawesi & $1.000 \quad(30)$ & $0.000(0)$ & $0.000(0)$ & 1.000 & 0.000 \\
\hline & Riau & $1.000 \quad(25)$ & $0.000(0)$ & $0.000(0)$ & 1.000 & 0.000 \\
\hline & West Sumatera & 1.000 & $0.000(0)$ & $0.000(0)$ & 1.000 & 0.000 \\
\hline & Sub Total & $1.000(250)$ & $0.000(0)$ & $0.000(0)$ & 1.000 & 0.000 \\
\hline
\end{tabular}

$(\ldots)=$ Number of samples; SBBC $=$ Siborong-borong Buffalo Breeding Center

CC, CT, and TT genotype was found in Deli Serdang (0.950), SBBC (0.350), and SBBC (0.050), respectively. Genotype $\mathrm{CC}$ was not found in Deli Serdang, but in that location showed same result as SBBC that the genotype CC (0.950) was higher than CT (0.050). The $\kappa$-Casein gene of swamp buffalo in all populations were monomorphic with one genotype, namely $\mathrm{CC}$ genotype.

The $\mathrm{C}$ and $\mathrm{T}$ alleles of riverine buffaloes in SBBC were 0.775 and 0.225 ; then 0.975 and 0.025 for Deli Serdang. The $\mathrm{T}$ and $\mathrm{C}$ alleles in swamp buffalo in all populations were 1.000 and 0.000 , respectively. Patel et al. (2007) who reported in their research with $\kappa$-Casein gene of water buffalo that the frequency of $\mathrm{BB}$ genotype (0.968) was very higher than $A B$ genotype (0.032) and AA genotype (0.00). This result indicating that most buffalo population has allele (B) for higher casein production.

Monomorphic allele in swamp buffalo was confirmed in several research in other countries, such as: India (Shende et al., 2009; Gangaraj et al., 2008), Mishr (Othman, 2005; Mahmoud et al., 2010; Dayem et al., 2008), Pakistan (Riaz et al., 2008), Brazil (Otaviano et al., 2005), Iran (Abassi et al., 2009), dan China (Ren et al., 2011).

\section{Polymorphisms Degrees of the к-Casein|EcoRV Gene}

Heterozygosity value is the most accurate way to measure the genetic diversity of population (Nei and Kumar, 2000) and to get an overview of genetic variability (Marson et al., 2005). Heterozygosity values are influenced by the number of samples, the number of alleles and allele frequencies. The result of heterozygosity analysis and PIC value in riverine and swamp buffalo shown in Table 3 .

Javanmard et al. (2005) suggest that heterozygosity values below $0.5(50 \%)$ indicate low variation of a gene in the population. Table 3 showed that the heterozygosity of riverine and swamp buffalo were low. In riverine buffaloes, the observation heterozygosity values were lower than expected heterozygosity $(\mathrm{Ho}=0.200<\mathrm{He}=$ $0.219)$ indicated that $\kappa$-Casein gene had a low level of heterozygosity. Swamp buffalo was not showed heterozygosity value because it was not showed allele variation. This might be caused by a lack attention on breeding program and there were no intensive selection based on the milk quality of 
Table 3. Observations Heterozygosity Values (Ho), Expected (He) and Polymorphic Informative Content (PIC) of $\kappa$-Casein Gene

\begin{tabular}{llccc}
\hline Buffalo Breed & \multicolumn{1}{c}{ Population } & Ho & He & PIC \\
\hline Riverine buffalo & SBBC (20) & 0.350 & 0.349 & 0.288 \\
& Deli Serdang (20) & 0.050 & 0.049 & 0.048 \\
& Sub Total & 0.200 & 0.219 & 0.195 \\
Swamp buffalo & Banten (30) & 0.000 & 0.000 & 0.000 \\
& North Sumatera (24) & 0.000 & 0.000 & 0.000 \\
& Semarang (30) & 0.000 & 0.000 & 0.000 \\
& Mataram (30) & 0.000 & 0.000 & 0.000 \\
& Aceh (67) & 0.000 & 0.000 & 0.000 \\
& South Sulawesi (30) & 0.000 & 0.000 & 0.000 \\
& Riau (25) & 0.000 & 0.000 & 0.000 \\
& West Sumatera(14) & 0.000 & 0.000 & 0.000 \\
& Sub Total & 0.000 & 0.000 & 0.000 \\
\hline
\end{tabular}

$(\ldots)=$ Number of samples; SBBC $=$ Siborong-borong Buffalo Breeding Center

$\kappa$-Casein gene in both location. Hartl and Clark (1997) reported that expected heterozygosity value can be used as a way to estimate the breeding value (inbreeding) in a group of livestock. Generally, the expectation value of heterozygosity is a good indicator as a genetic identifier that can explain the genetic diversity in a population of domestic livestock (Moioli et al., 2004).

Besides heterozygosity value, polymorphism of a gene can be determined by calculating the PIC value. PIC value describe the values of corrected heterozygosity by the partially informative mating. PIC value have ranged from 0 - 1 . PIC value equal null $(\mathrm{PIC}=0)$ when only one allele is found in the genetic markers, whereas the PIC values equal one $(\mathrm{PIC}=1)$ if there were an infinite number of alleles. If a gene has two alleles it will produce the maximum PIC value of 0.375 (Hildebrand et al., 1992).

Based on Tabel 3, PIC value equal null (PIC $=0$ ) were found in all populations of swamp buffaloes because in those location $\kappa$-Casein| EcoRV gene were monomorphic found only one allele, namely $\mathrm{C}$ allele. PIC value in riverine buffaloes was higher in SBBC $(\mathrm{PIC}=0.288)$ than
Deli Serdang $(\mathrm{PIC}=0.048)$.

\section{Fixation Index of к-Casein|EcoRV gene}

Fixation index can be used to determine breeding pattern and selection in population. The value of fixation index could be positive or negative, it was influenced by selection, inbreeding, and assortative mating. The highest fixation index values in this study were low (Table 4). The $\kappa$-Casein gene was in fixation in swamp buffaloes in all populations due to a monomorphic occurrence. The fixation process could be caused by inbreeding in all populations swamp buffaloes were observed (Nei and Kumar, 2000)

\section{CONCLUSION}

$\kappa$-Casein $\mid E c o \mathrm{RV}$ gene in riverine buffalo in SBBC and Deli Serdang was polymorphic, with two alleles, namely $\mathrm{C}$ and $\mathrm{T}$ allele. $\kappa$-Casein EcoRV gene in swamp buffalo was monomorphic with one allele, namely $\mathrm{C}$ allele. Heterozygosity value in riverine and swamp buffaloes were low (ranged from $0.000-0.350$ ). Fixation Index values in riverine and swamp buffalo were low. The $\kappa$-Casein gene was in fixation in swamp 
Table 4. Fixation Index of $\kappa-$ Casein Gene

\begin{tabular}{lcc}
\hline \multicolumn{1}{c}{ Population } & Allele & FISKI \\
\hline Riverine Buffalo & & \\
SBBC & $\mathrm{T}$ & -0.0036 \\
& $\mathrm{C}$ & -0.0036 \\
Deli Serdang & $\mathrm{T}$ & -0.0256 \\
& $\mathrm{C}$ & -0.0256
\end{tabular}

Swamp Buffalo

\begin{tabular}{lcc} 
Banten & $\mathrm{T}$ & 0.000 \\
\multirow{2}{*}{ North Sumatera } & $\mathrm{C}$ & 0.000 \\
\multirow{3}{*}{ Semarang } & $\mathrm{T}$ & 0.000 \\
\multirow{2}{*}{ Mataram } & $\mathrm{C}$ & 0.000 \\
\multirow{3}{*}{ Aceh } & $\mathrm{T}$ & 0.000 \\
& $\mathrm{C}$ & 0.000 \\
South Sulawesi & $\mathrm{T}$ & 0.000 \\
\multirow{2}{*}{ Riau } & $\mathrm{C}$ & 0.000 \\
& $\mathrm{~T}$ & 0.000 \\
West Sumatera & $\mathrm{C}$ & 0.000 \\
& $\mathrm{~T}$ & 0.000 \\
& $\mathrm{C}$ & 0.000 \\
& $\mathrm{~T}$ & 0.000 \\
& $\mathrm{C}$ & 0.000 \\
\hline
\end{tabular}

SBBC $=$ Siborong-borong Buffalo Breeding Center; $\mathrm{F}_{\text {ISki }}$ : Fixation Index

buffaloes in all populations due to a monomorphic occurrence

\section{ACKNOWLEDGMENTS}

The authors acknowledge to Indonesian Agency for Agricultural Research and Development (IAARD) as funders in this projects and thanks to the Head and staff of Siborongborong Buffalo Breeding Center for providing blood samples.

\section{REFERENCES}

Abbasi, B. J. Fayazi, M. T. B. Nasiri, H. A.
Roshanfekr, Kh. Mirzadeh and A.S. Sadr. 2009. Analysis of kappa-casein gene polymorphism by PCR-RFLP buffalo population in Khouzestan province. Res. J. of Biol, Sci. 4 (10): 1073-1075.

Alipanah, M., L. A. Kalashnikova and G. V. Rodionov. 2008. Kappa-casein and PRLRSAI genotypic frequencies in two Russian cattle breeds. Arch. Zootechnol. 57(218): 131-138.

Andreas, E, C. Sumantri. H. Nuraini. A. Farajallah and A. Anggraeni. 2010. Identification of $\mathrm{GH} \mid A l u \mathrm{I}$ and GHR|AluI Genes Polymorphisms in Indonesian Buffalo. J.Indonesian Trop.Anim.Agric. 35:215-221.

Bostein DR, White L, Skolnik M, dan Davis RW. 1980. Construction of a genetic linkage map in man using restriction fragment length polymorphisms. Am J Hum Genet 32: 314.

Chiatti, F., A. Caroli, S. Chessa, P. Bolla and G. Pagnacco. 2005. Relationships between goat $\kappa$-casein (CSN3) polymorphism and milk composition. FAO The role of biotechnology, 369 Villa Gualino, Torino 2-5 Marzo, 163-164.

Dayem, A. M. H. A., K. Gh.. M. Mahmoud, M. F. Nawito, M. M. Ayoub and S. F. Darwish. 2008. Genotyping of kappa-casein gene in egyption buffalo bulls. Lives. Sci. 122: 286289.

Di Stasio, L. and P. Mariani. 2000. The role of protein polymorphism in the genetic improvement of milk production. Zootecnica e Nutrizione Animale. 26:69-90.

El-Rafey, G. A and S. F. Darwish. 2007. A PCRRFLP assay to detect genetic variants of kappa-casein gene in cattle and buffalo. Arab J. Biotech. 11(1): 11-18.

Gangaraj, D. R., S. Shetty, M. G. Govindaiah, C. S. Nagaraja, S. M. Byregowda and M. R. Jayashankar. 2008. Molecular characterization of kappa-casein gene in buffaloes. Sci. Asia. 34:435-439.

Grosclaude, F. 1988. Le polymorphisme genetique des principales lactoproteines bovines. INRA Prod. Anim. 1:5-17.

Hartl, D. L and A. G. Clark. 1997. Principle of Population Genetics. Sinauer Associates, Inc. Publishers. Sunderland.

Henderson, J. L. 1971. The Fluid-milk Industry. Vol.2. AV I London, UK.

Hildebrand CE, Torney DC, Wagner RP. 1992. Informativeness of polymorphic DNA markers. Los Alamos Sci. 20:100-102. 
Iannuzzi, L. 1998. A genetic physical map in river buffalo. Carylogia. 51:311-318

Javanmard, A., N. Asadazadeh., M. H. Banabazi and J. Tavakolian. 2005. The allele and genotype frequencies of bovine pituitary specific transcription factor and leptin genes in Iranian cattle and buffalo populations using PCR-RFLP. Irianian J. of Biotechnol. 3:104-108.

Ke Xiayi, Collins A, Ye S. 2001. PIRA PCR designer for restriction analysis of single nucleotide polymorphism. Bioinformatics Appl. Note. 17(9):838-839.

Mahmoud, K.Gh. M., M. F. Nawito and A. M. H. A. Dayem. 2010. Sire selection for milk production traits with special emphasis on Kappa Casein (CSN3) gene. Global J. Mol. Sci. 5(2):68-73.

Marson, E. P., J. B. S. Ferraz, F. V. Meirelles, J. C. D. C. Balieiro, J. P. Eler, L. G. G. Figueiredo and G. B. Mourau. 2005. Genetic characterization of European Zebu composite bovine using RFLP markers. Genet. Mol. Res. 4:496-505.

Masina, P., A. Rando, P. Di Gregorio, G. Cosenza and A. Mancusi. 2007. Water buffalo kappacasein gene sequence. Ital. J. Anim. Sci. 6: 353-355.

Medrano, J. F. and E. C. Aguilar. 1990. Genotyping of bovine kappa-casein loci following DNA sequence amplification. BioTechnol. 8:144-146.

Mitra, A., P. Scalee, I. Krause, J. Blusch, T. Werner, C.R. Balakrishnan and F. Pirchner. 1998. Kappa-casein polymorphisms in Indian dairy cattle and buffalo: a new genetic variant in buffalo. Anim. Biotechnol. 9:8187.

Moioli B., F. Napolitano and G. Catillo. 2004. Genetic diversity between Piedmontese, Maremmana, and Podolica cattle breeds. J. Hered. 95: 250-256.

Nei, M. 1987. Molecular Evolutionary Genetics. Columbia University Press Ed. New York. pp.52

Nei, M. and S. Kumar. 2000. Molecular Evolution and Phylogenetics. Oxford University Press, New York.
Otaviano, A. R., H. Tonhati, J. A. D. Sena and M. F. C. Munoz. 2005. Kappa-cassein gene study with molecular markers in female buffalo (Bubalus bubalis). Gen. Mol. Biol. 28 (2): 237-241.

Othman, O. E. 2005. The identification of kappacasein genotyping in Egyptian river buffalo using PDR-RFLP. Arab J. Biotech. 8(2): 265-274.

Patel, R. K., J. B. Chaulan, K. M. Singh, and K. J. Soni. 2007. Genotype and allele frequencies of k-casein and B-lactoglobulin in Indian river buffalo bulls (Bubalus bubalis). Buffalo Bulls. 26 (3): 63-66.

Rachagani, S. and I. D. Gupta. 2008. Bovine kappa-casein gene polymorphism and its association with milk production traits. Gen. and Mol. Biol. 31(4):893-897.

Raj, G. D., S. Shetty, M.Govindaiah, C. S. Nagaraja, S. M. Byregowda and M. R. Jayashankar. 2008. Molecular characterization of kappa-casein gene in buffaloes. Sci. Asia. 34: 435-439.

Ren, D., S. Miao, Y. Chen, C. Zou, X. Liang and J. Liu. 2011. Genotyping of the k-casein and $\beta$-lactoglobulin genes in Chinese Holstein, Jersey and water buffalo by PCR-RFLP. J. Genet. 90: e1-e5.

Riaz, M. N., N. A. Malik, F. Nasreen, S. Sadaf and J. A. Qureshi. 2008. Molecular marker assisted study of the kappa-casein gene in Nili-Ravi buffalo of Pakistan. Buffalo Bulletin. 27 (3): 240-244.

Sambrook, J., E. F. Fritsch and T. Maniatis. 1989. Molecular Cloning, A Laboratory Manual. 2nd ed. Cold Spring Harbour Lab. Press, New York.

Shende, T. C., M. P. Sawane and V. D. Pawar. 2009. Genotyping of Pandharpuri buffalo for k-casein using PCR-RFLP. Tamilnadu J. Vet. Anim. Sci. 5 (5): 174-178.

Unsal, D., O. Memis and E. Sezai. 2008. Genetic polymorphism in Kappa-casein gene detected by PCR-RFLP in cattle. J. Applied. Anim. Res. 33 (1): 971-2119.

Weir, B. S. 1996. Genetic Data Analysis II : Method for Discrete Population Genetic Data. $2^{\text {nd }} E d$. Sinauer Associates. Sunderland. 